\title{
Impact of climate change on arid lands agriculture
}

\author{
Adel El-Beltagy and Magdy Madkour ${ }^{*}$
}

\begin{abstract}
The planet earth, on which we live in communities, is being increasingly 'ruptured' because of human activities; its carrying capacity is under great stress because of demographic pressures. The pressure is especially affecting the people living in the dry areas because of the marginal and fragile nature of the resources they have access to. There are over 2,000 million hectares of land that have been degraded, with a loss of agrobiodiversity, increased water scarcity and increased natural resource destruction. Superimposed on this is the fact that the neglectful and exploitive use of natural resources has set the train of global climate change in motion.

It is anticipated that the impact of climate change will cut across all boundaries. Crops, cropping systems, rotations and biota will undergo transformation. To maintain the balance in the system, there is a need for new knowledge, alternative policies and institutional changes. The marginalized people in dry areas are likely to be most seriously hit by the shifts in moisture and temperature regimes as a result of the global climate change. To help them cope with the challenges, there is a need for a new paradigm in agricultural research and technology transfer that makes full use of modern science and technology in conjunction with traditional knowledge. This necessitates more investment by international agencies and national governments for supporting the relevant integrated research and sustainable development efforts, with full participation of the target communities. Only such an approach can enable the vulnerable communities of the dryland areas to use the natural resources in a sustainable manner and thus help protect the environment for future generations.

The clock is ticking and the future of the world lies in the collective responsibility and wisdom of all nations on this planet. This should be reflected in the endorsement of a solid future plan.
\end{abstract}

Keywords: Adaptation, arid lands, biotechnology and nanotechnology, climate change, drought tolerance, drylands, mitigation, water resources

\section{Climate change; expected impacts}

Our planet is figuratively 'on fire'. The increase in global temperature is evident (Figure 1). The reports of the Intergovernmental Panel on Climate Change (IPCC) clearly indicate that the temperature has increased and it is anticipated to increase further in the future unless measures are taken $[1,2]$. What was projected to happen by the year 2100 is going to happen earlier than expected. The melting of the glaciers and disappearing ice sound an alarm as to what might come in the future.

In addition to the raised temperatures, there is going to be a rise in seawater level (Figure 2), which will have grave implications for countries whose lands are at elevations

\footnotetext{
* Correspondence: madkour.magdy@gmail.com

Arid Lands Agricultural Research Institute (ALARI), Faculty of Agriculture, Ain Shams University, Shobra El Kheima, Cairo, Egypt
}

similar to sea level. For example, nearly $1,800 \mathrm{~km}$ of land on the north coast of Egypt and the Nile delta will be under seawater if there is a rise of $50 \mathrm{~cm}$ in the sea level, affecting 3.8 million people.

Many of the old deltas, where agriculture first started, are amongst those that are most threatened by a rise in sea levels. Not only will there be a loss of land and its productivity but also people living there will have to migrate to higher (and therefore, safer) lands, adding to social and economical problems there. Tension will increase between communities and wars might even erupt, as has been happening between people who have historically depended on rangelands and those who practice settled agriculture. Many of the countries where migrants might arrive are likely to be economically advanced countries, and these developed countries might

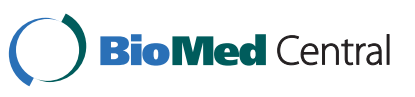




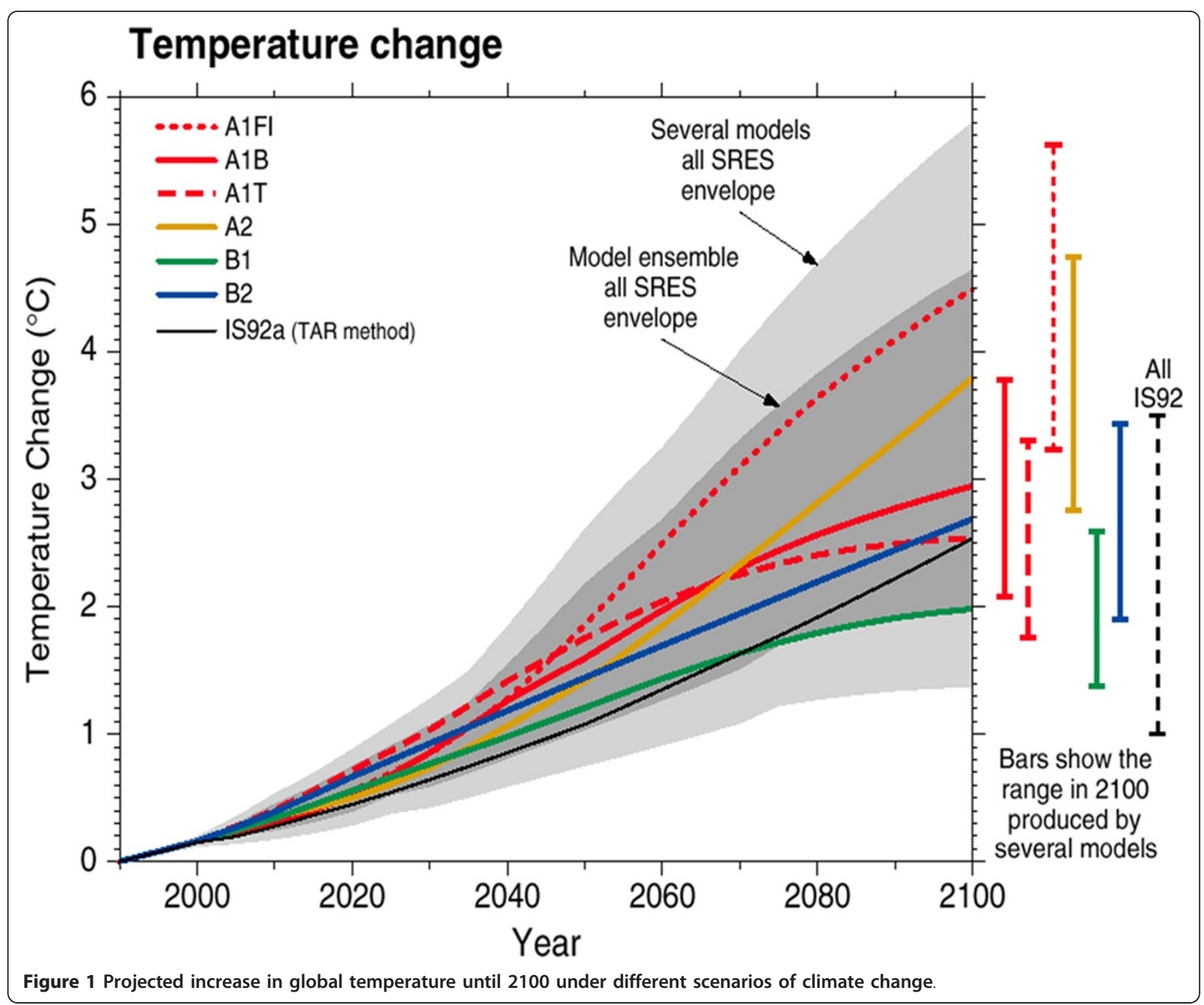

then face social and political upheavals. Political tension between the nations might grow. Environmental refugees and out-migration resulting from the impact of climate change should be superimposed on future studies of outmigration (Figure 3) [3]. The frequency of flooding and hurricanes will increase, causing damage to life and property with enormous costs to the nations [4].

The change in precipitation is already occurring. Wet areas are likely to become wetter and dry areas will become drier, increasing water scarcity in these dry areas (Figure 4). The water poverty indicators show that the maximum decrease is going to occur in the West Asia and North Africa (WANA) region. Climate change will also affect aquaculture, which is the fastest growing food production sector in the world and is a good source of revenue to the people, particularly the poorer communities.

According to the World Fish Center, a rise in the temperature of inland water may reduce the wild fish stock by harming water quality, worsening dry season mortality, bringing predators and new pathogens and changing the abundance of food available [5]. There will be a need for ecosystems-based policies, plans and projects for aquaculture to cope with the climate change.

There is compelling evidence, as presented in the IPCC reports $[1,2]$, that the climate change will seriously affect the sustainable development challenges that we face not only in environmental issues but also in other areas. The climate change is not going to be country-selective but the fact remains that the developing countries are going to suffer the most, especially the poorer countries. Climate change will undermine the ability of developing countries to attain millennium development goals and achieve sustainable development.

With all these negative impacts of climate change, the question arises as to whether the situation is really this grim and will the world be able to survive. Pessimists hold the view that the future of the world is under great 


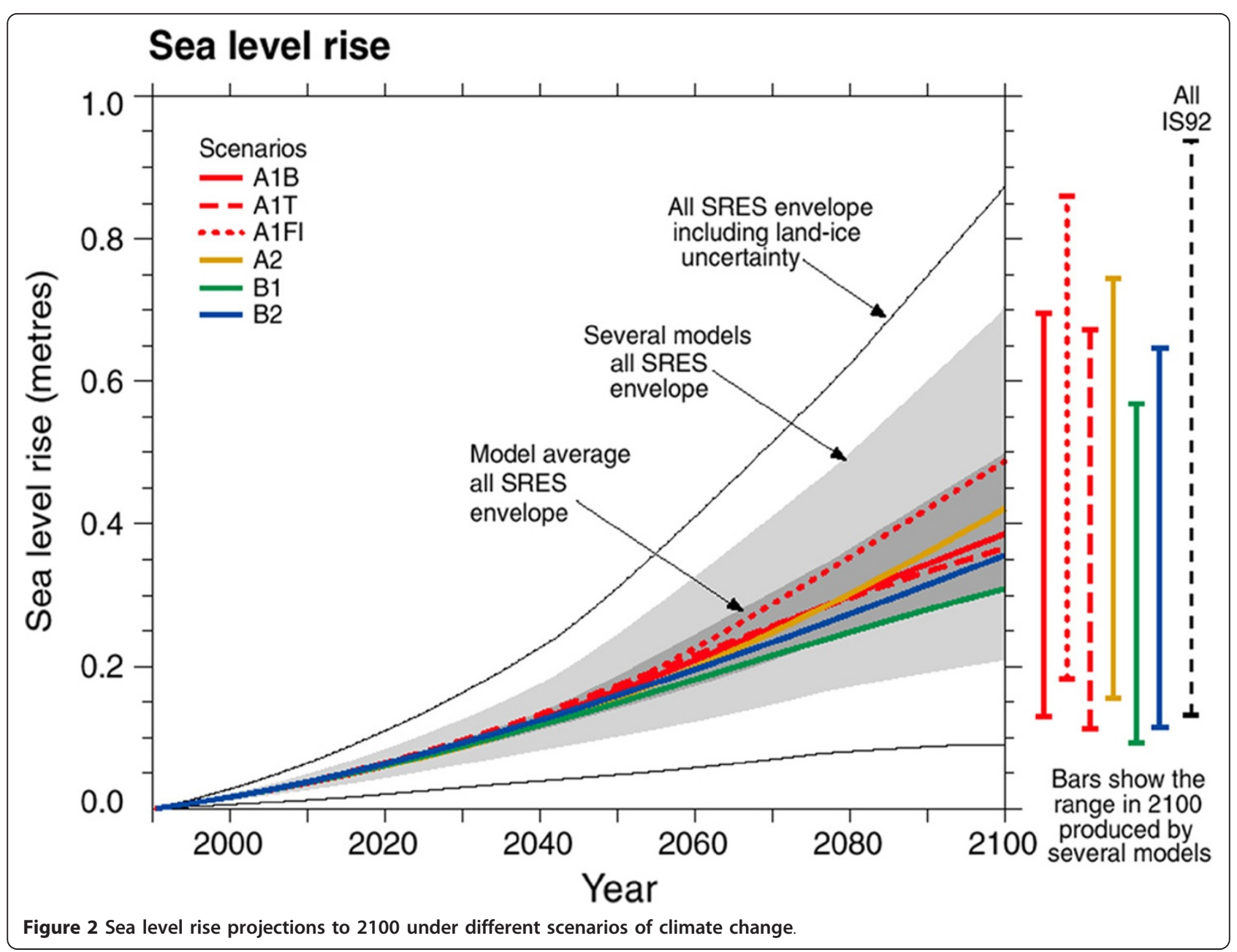

risk because of the constraints on natural resources and degradation of the environment. Optimists project that human ingenuity will always find ways or develop substitutes to deal with the scarcity of natural resources; they strongly believe in human resilience [4].

\section{Enhancing human resilience to cope with impacts of climate change}

Climate change is going to have a drastic impact on dryland ecosystems and its almost 2.5 billion inhabitants [6]. All the climate models used by the IPCC suggest that the dry areas will become dryer and more waterstressed [1,2]; add to this the degradation and erosion of the soil and desertification will become irreversible.

The dryland areas (40\% of world land surface; Figure 5) are home to over 2 billion people, accounting for $35 \%$ of the world's population. Some $55 \%$ of dryland inhabitants live in rural areas. More than $90 \%$ of dryland inhabitants are in the developing world and $70 \%$ in rural areas. Approximately half of the poorest people in the world live in the dry areas [7].
The drylands have the highest population growth rates. These statistics highlight the importance of dry areas in the global community. One may ask why climate change is of specific significance to the dryland areas. There are several factors. Most dryland ecosystems are already affected by increasing resource demands and unsustainable management practices, and human-induced climate change adds an important new stress. Most dryland systems are sensitive to both the magnitude and rate of climate change, and the vulnerability of the people living in these areas is going to increase if their adaptive capacity is not improved.

The direct effects of the climate change will be through changes in temperature, rainfall, length of growing season and timing of extreme and critical threshold events relative to crop development. In the dryland of the tropics and subtropics, where crops are near their maximum temperature tolerance level, the yield will decline. In the regions where there is likelihood of decreased rainfall, agriculture productivity will be seriously impaired. 


\section{Relative water scarcity projections to 2025}
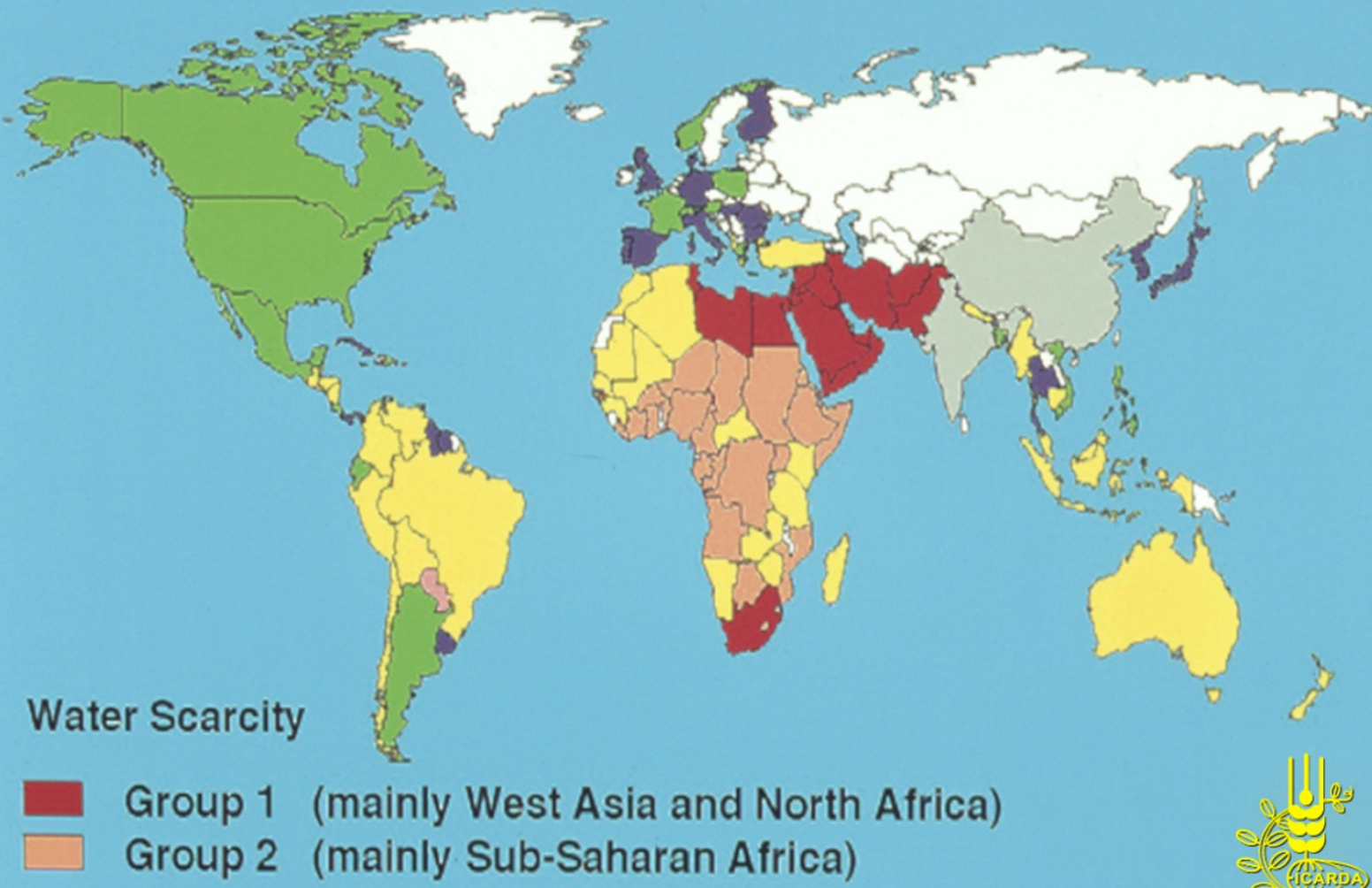

Figure 3 Migration projections from arid lands of the West Asia and North Africa region to Europe

Drought is a recurring feature of drylands and climate change will further exacerbate the frequency and magnitude of drought in some places. In the arid and semi-arid regions, people drive their water resources from single point systems. If the primary supply fails, these systems are vulnerable. The impact will depend on the baseline conditions of the water supply system, but also on population growth, changes in demand, technology available and socioeconomic and legislative conditions.

The dry areas are highly variable spatially. Global modeling of climate change can only provide information in general terms because their resolution is too coarse to capture regional and local climate processes. To develop strategies that can enhance the resilience of different communities in the dry areas there, it is necessary to go further down in the assessment exercise from the global to continental, regional, national and, finally, to local levels, looking at mitigation and adaptation strategies (Figure 6). This is because the global assessment masks the regional difference, regional assessment masks the sub-regional differences, and national assessment masks the local differences in ecologies. Thus, navigation across scales is essential for making progress towards sustainable development, and the task of assessment at lower levels should not be delayed if the resilience of the affected communities is to be promptly and cost-effectively enhanced.

Enhancing the resilience of communities to cope with climate change would require a series of steps:

1. Running awareness campaigns for the need for resilience.

2. Studying the strategies for enhancing resilience.

3. Developing goals and implementing action plans to encourage 'shared problems' and 'opportunity focus' among partners.

4. Facilitating access to risk-reducing technologies and practices to enhance the capacity of local communities to cope with climate change.

5. Developing clear partnerships and collaborative arrangements built on trust ownership and joint commitment to vision and impacts. 


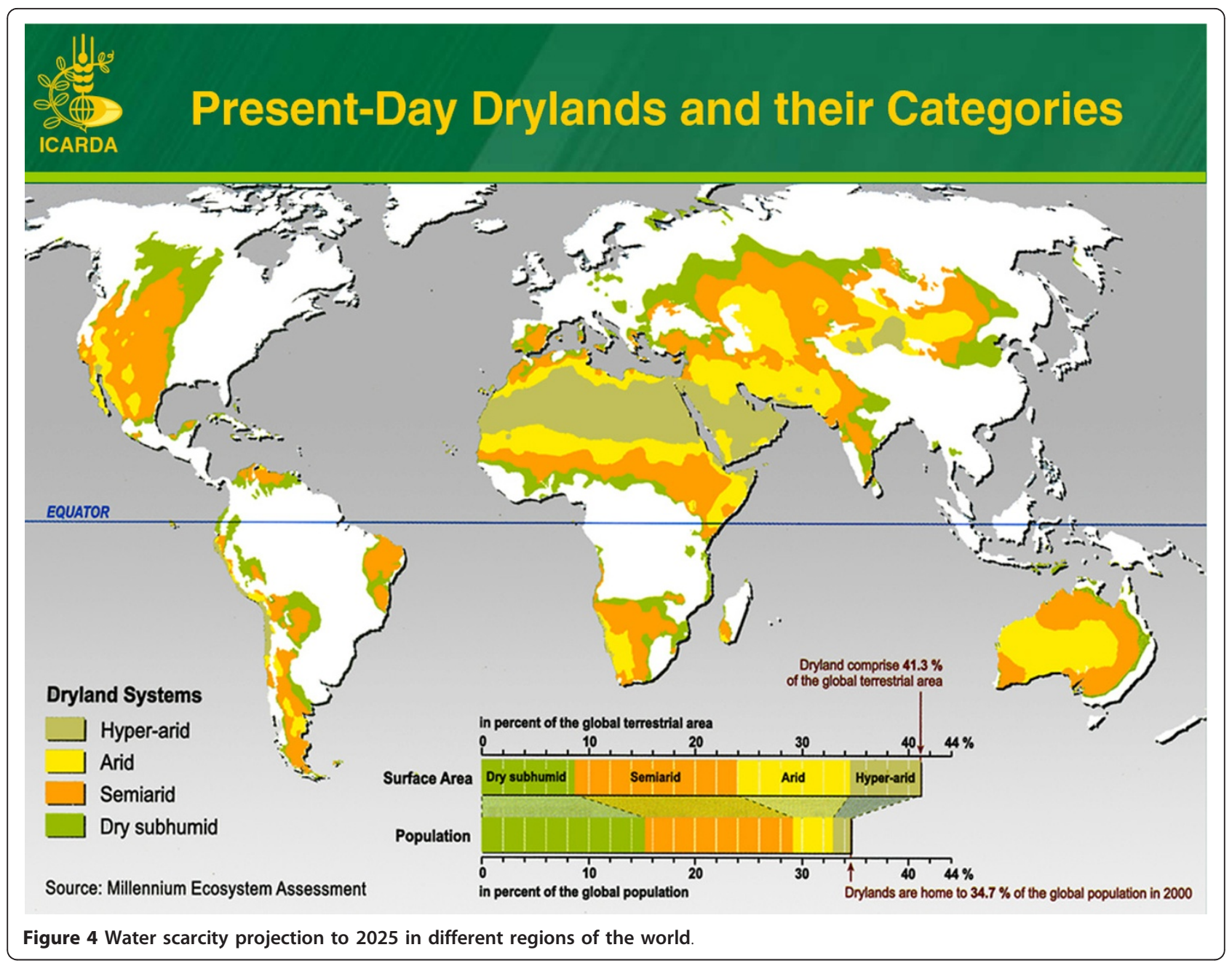

6. Empowering female participation in local communities' organizations.

7. Enabling environmental policy and institutional arrangements to exploit the improved technologies.

8. Encouraging agricultural biodiversity and diversification of production systems and livelihood sources. 9. Applying safety net measures.

10. Measuring progress and identifying lessons learned [8].

\section{Population and poverty}

Compounding these problems is the expanding world population, which is predicted to reach at least 8 billion by 2020 . By November 2011, we had already reached 7 billion. Much of the population growth is projected to take place in the south, where millions of people are already under the severe grip of poverty [7].

More than one billion people living in poverty inhabit the dry areas in the developing world. Over 750 million of these are located in Central and West Asia and North
Africa (CWANA) region. The picture of poverty in CWANA is often distorted by averaging the income of those with low-income with those with high-income. The oil exporters of the Arabian Peninsula and Central Asia represent only $5 \%$ of the region's population. The remaining $95 \%$ of the region's population has low per capita income. Of these, some $76 \%$ have a mean per capita income of less than two US dollars a day, and about $42 \%$ live on one dollar a day. Across WANA, women account for about half of the agricultural labor force.

There is greater absolute poverty in rural areas than in urban areas. For example, 59\% of the combined populations of Afghanistan, Eritrea, Somalia, Sudan and Yemen live below the one-dollar-a-day poverty line and $90 \%$ of these live in rural areas. Economic disparities will continue to encourage migration from rural to urban areas and from poorer to wealthy countries. This will cause sociopolitical upheavals. Can the world survive these problems or will it crack under the pressure? We must continue to work hard to make the future of this planet sustainable $[7,9,10]$. 


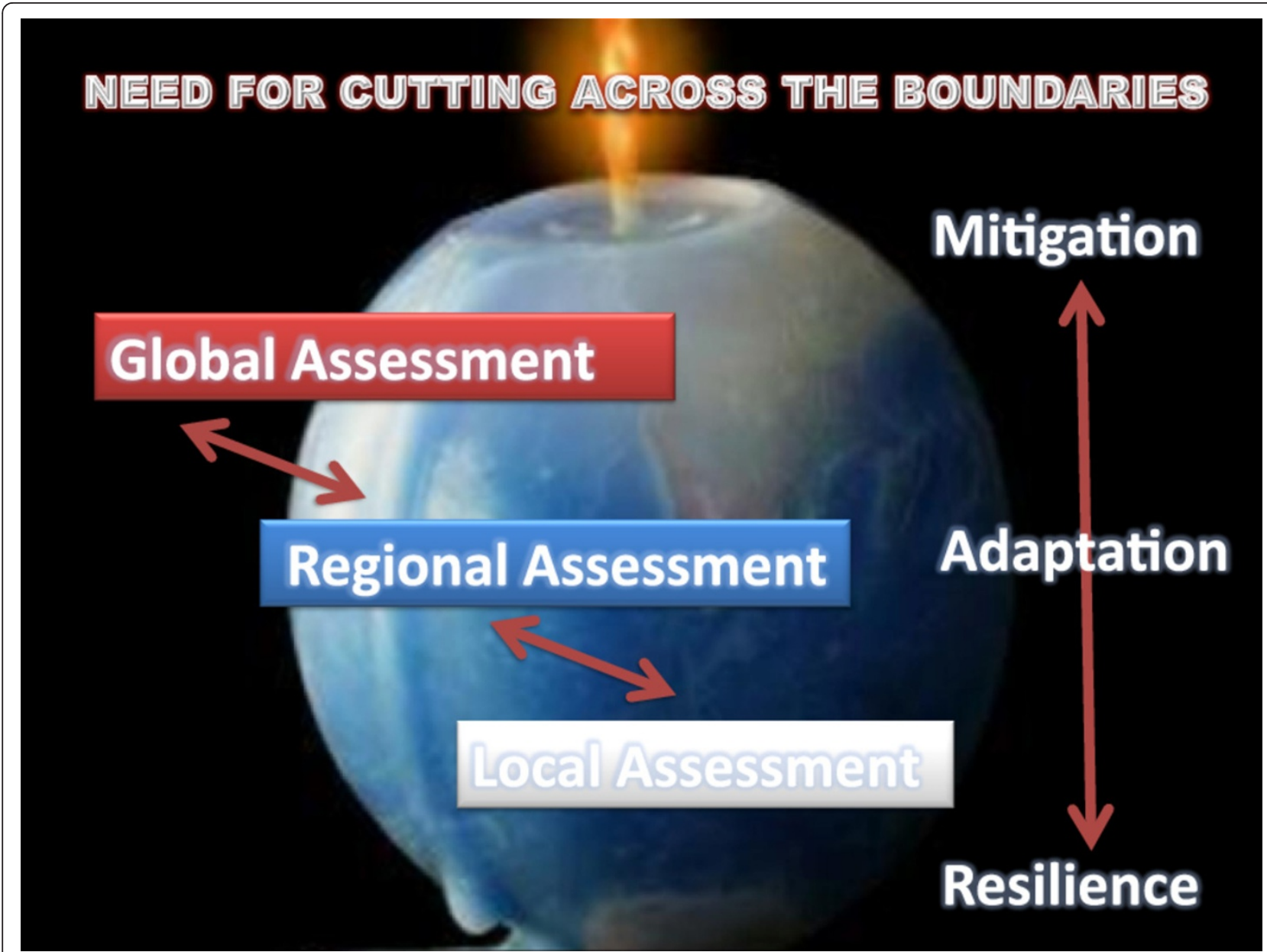

Figure 5 Dryland areas of the world (source: Millennium Ecosystem Assessment 2005)

Impact of climate change on arid land resources Water resources

Water is becoming scarce not only in arid and droughtprone areas, but also in regions where rainfall is abundant. Water scarcity concerns the quantity and the quality of the resource available, because degraded water resources are considered unusable for more stringent water uses. The sustainable use of water - resource conservation, environmental friendliness, appropriateness of technologies, economic viability and social acceptability of development issues - is therefore a priority for agriculture in water-scarce regions [11].

The WANA region has the lowest per capita renewable water resources. Some countries are already facing an acute shortage of water (for example, Jordan, Palestine) and others are projected to fall into the same category in the very near future. Water is the single most important commodity, which, if cheaply accessible, can fundamentally alter the potential of a low-rainfall area [4]. Despite its scarcity in WANA, water continues to be misused. New technologies have increased the capacity to extract water to levels exceeding recharge, thereby depleting aquifers to exhaustion. Modern facilities can promote desertification. The ease of transportation has enables herders to take water for their livestock to the sites of grazing, promoting overgrazing on the same piece of land, which ultimately leads to wind erosion and loss of biodiversity. These are some of the key issues contributing to increased desertification, global warming, famine and starvation of millions of people.

\section{Land resources}

The livelihoods of more than 900 million people in some 100 countries are now directly and adversely affected by land degradation. Unless the current rate of degradation is slowed and reversed, the food security of humanity will be threatened and the ability of poorer nations to increase their wealth through improved productivity will be impeded. Land degradation can be observed in all agroclimatic regions on all continents. Although climatic conditions, such as drought and floods, contribute to degradation, the main causes are human activities. Land degradation is a local problem in a vast number of 


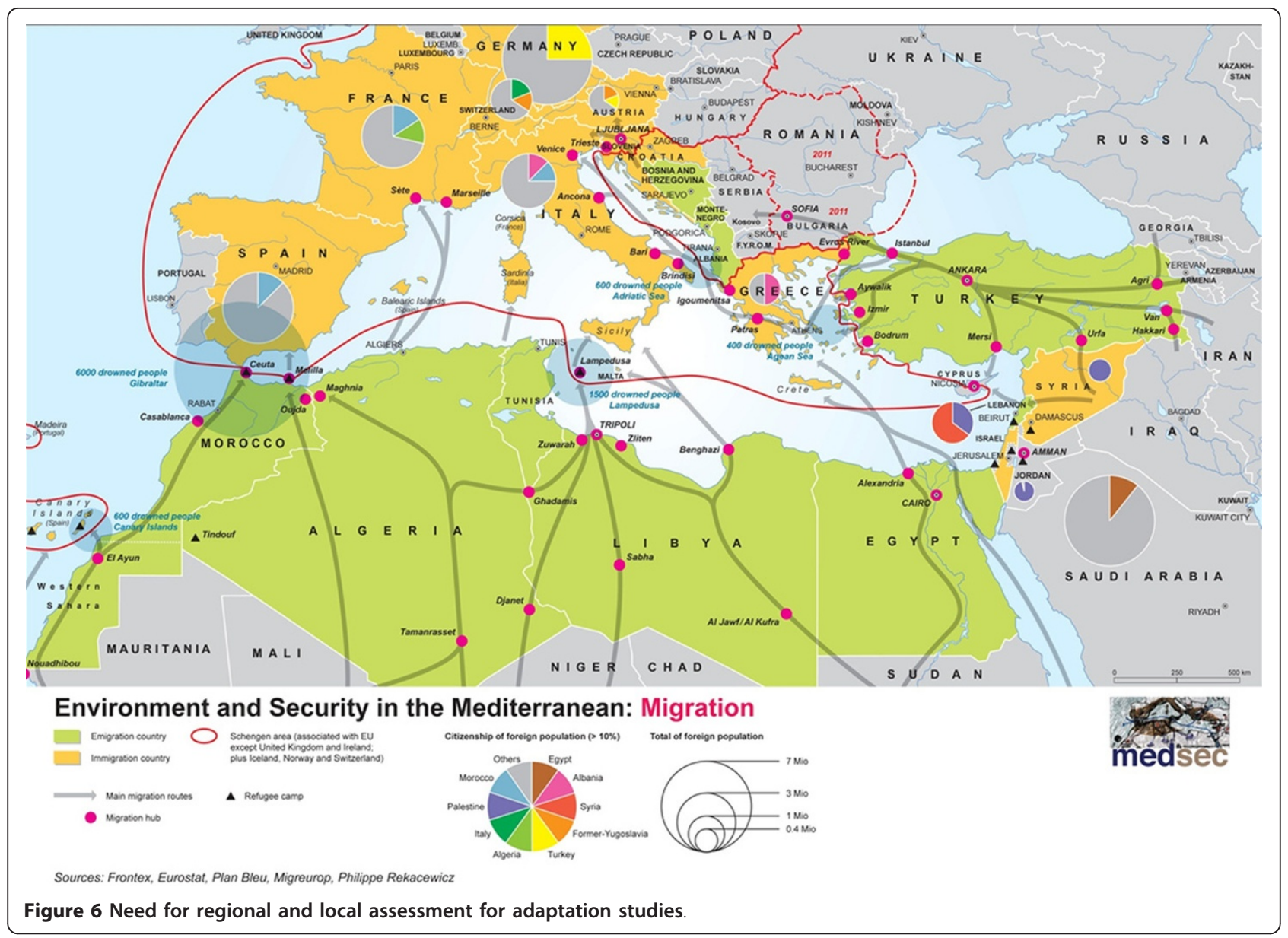

locations, but it has cumulative effects at regional and global scales. The countries of the developing world, and particularly those in the arid and semi-arid zones, are the most seriously affected.

Land degradation is a universal problem. We must not be misled into thinking it is restricted to agricultural land or agricultural livelihoods, although it is in these areas that the effects of land degradation are immediately apparent and most dramatic. In the developing world, land degradation is a symptom of underdevelopment. It results from a combination of social and economic factors, such as poverty and inequitable distribution of the land resources, and inappropriate land-use systems and farming methods. In the dry areas, these factors are exacerbated by climate and the fragility of the ecosystems. Because agriculture in the poorer countries is the principle employer of labor and generator of income, the effects of land degradation are often disastrous and lead to famine and political turmoil [12].

\section{Crops and genetic diversity}

Desertification and climate change will greatly impact plant biodiversity. Traditionally, the gene banks in different institutions have collected, evaluated and conserved the germplasm of different plants under short- and longterm storage conditions. With the initiative of the Scandinavian countries and the Global Crop Diversity Trust, the conservation efforts have moved further to store germplasm in the facilities created in the arctic permafrost. The idea is to have valuable and diverse genes of important species conserved for posterity and to provide resources for developing cultivars that might adapt to new ecoenvironments [4]. The development of new plant varieties with low-water requirements, better water-use efficiency and the production of drought-tolerant varieties can help increase food production.

The WANA region is well known as the home of some of the most widely cultivated crops in the world. The region contains three of the eight centers of crop origin identified by Nikolai Vavilov. Barely, wheat, lentil and vetch were all domesticated in the Near East. The wild progenitors and relatives of these crops occur in the region to this day, as indicated by results of the International Centre for Agricultural Research in the Dry Areas' (ICARDA) studies on the distribution of wild relatives of wheat. The biodiversity locked up in wild relatives of the crops that originated in the region is under serious threat 
from desertification. Fencing can provide one simple solution to protect biodiversity and arrest desertification, but only when the soil seed-bank has not blown away or died out. Areas must not be fenced for too long, or else plant species unpalatable to livestock will dominate the habitat. Grazing, if properly managed, is an integral part of rangeland management [4].

Prolonged overgrazing of rangeland and of crop residues in harvested fields weakens and degrades the vegetation, and results in the depletion of plant diversity and reduced biomass production. The latter turn leads to reduced soil organic matter and deterioration of the soil structure [12].

\section{Adaptation measures to climate change Management of water resources}

There is no doubt that improving the productivity of water in dry areas will continue to be a priority. Efforts to direct new research and the transfer of available technologies to overcome water shortages are very much needed. Coordination of these efforts within an agreedupon framework may enhance their impact. Elements of the research and technology framework would include:

1. The development of alternative land-use systems and cropping patterns for improved water use that are economically competitive and that respond to changing markets and demands in various agroecologies and socioeconomic situations.

2. The development and transfer of alternative irrigation technologies with high water productivity and suitable for irrigation in these alternative land-use systems.

3. Developing new guidelines for irrigation scheduling under water-scarce conditions. Conventional guidelines are suitable only under normal water supply.

4. Developing methodologies for assessment of water use at basin level of representative areas for evaluating the amounts of depleted and recoverable water and the economic returns.

5. Improving crop materials (germplasm) for higher water productivity in addition to the conventional target of high yield.

6. Evaluating the environmental consequences of conservative management of scarce water and ways to mitigate adverse effects.

7. Maintaining a balance between water allocation for food and for the environment under dry conditions.

8. Providing socioeconomic incentives for improved water management at the farm level and development of appropriate policies [13].

\section{Rehabilitation of marginal lands}

Semi-arid landscapes are particularly vulnerable to degradation because of sparse vegetative cover and the distribution of annual rainfall in a small number of intense storms. In addition, soil erosion 'hotspots' - where human-induced erosion is high due to topography, climate and population growth - occur in regions vulnerable to climate variability and change. These include the Andes and Central American highlands, China's Loess Plateau, the West African Sahel, and highland areas of eastern and southern Africa. Also, the Central Asian drylands have become more vulnerable to degradation because of the increased prevalence of poverty and a heightened risk of desertification. The adoption of conservation agricultural practices, such as conservation or zero tillage and crop residue management, green manures and agroforestry, as well as appropriate crop rotations lessen the risk of accelerated soil erosion from climate change and, in some cases, generate economic benefits that buffer against increased climate risks [14].

The greatest potential for mitigation in agriculture exists in changing cropland and rangeland management practices to enhance carbon sequestration, given the scale at which agriculture is practiced worldwide. Over the next 40 years, conservation agricultural practices will have the technical potential to restore more than half of the carbon lost (50 gigatonnes) from the world's agricultural soils currently under cultivation. The majority of these mitigation strategies also improve the adaptive capacity of production systems through:

1. Improved crop moisture management to cope with warmer temperatures and prolonged intervals between rainfall.

2. Reduce soil erosion, runoff and flooding risk.

3. Income generation from secondary agroforestry and legume green manure products, and intensification of small-scale livestock production.

4. Stabilization of the resource base as a foundation for diversifying agriculture and rural livelihoods in order to facilitate adaptation to longer-term impacts of climate change.

In turn, reducing soil erosion risk and increasing land productivity enhance the strength of the carbon flux from the atmosphere to biomass and from biomass to soils [15].

\section{Potential trade-offs between mitigation and adaptation}

Although very good potential exists for realizing synergies between mitigation and adaptation, potential trade-offs need to be considered as well. For example, adaptation can contribute to a growth in agricultural emissions where increased rates of fertilizer (nitrogen) are applied 
to compensate for climate-induced production losses in crop- and pastureland leading to increased nitrous oxide $\left(\mathrm{N}_{2} \mathrm{O}\right)$ emissions; changes in agricultural land management practices, such as conversion from conventional to zero tillage or the introduction of nitrogen-fixing agroforestry species, can increase $\mathrm{N}_{2} \mathrm{O}$ emissions from agricultural lands; or introduction of mid-season drainage of paddy rice or conversion from flooded to upland rice for water conservation can increase $\mathrm{N}_{2} \mathrm{O}$ emissions and potentially increase carbon dioxide emissions.

Mitigation can undermine adaptation in situations where bioenergy crops compete directly for land needed to ensure food security in climate-sensitive regions; tree species suitable for carbon sequestration may not be desirable from a rural livelihoods perspective; or afforestation in high watersheds may reduce water availability downstream [15].

Countries will witness an increasing budget load for livestock production and import. Research conducted by National Agricultural Research Systems and ICARDA over 10 years within the Mashreq-Maghreb project, which addressed crop-livestock integration, community development and improving livelihoods of agropastoral communities in eight countries of WANA, suggests integrated technical, institutional and policy options to help build coping strategies:

1. Help livestock keepers build strong institutions that can facilitate both collective and individual adaptation and response to climate change and other external pressures, both short and long term; and assure the participation of the livestock keepers in devising coping and risk management approaches to climate change through awareness building and collective action.

2. The increased pressure on rangelands will require an innovative approach to their sustainable improvement and management including institutional solutions for access to communal and collective ranges.

3. Better use of local natural resources with an emphasis on water harvesting and judicious use of adapted indigenous plant species, such as cactus and fodder shrubs, and introduction of feed blocks using agricultural by-products as well as treated straw.

4. More attention should be paid to devising efficient animal nutrition and health management options.

5. Better integration of cereals and livestock production should be pursued, with more attention to the value adoption of adequate rotations and conservation agriculture techniques that maintaining the natural resource base for sustainable development.

6. Use of biotechnology as a potentially effective tool to breeding drought-resistant forages and cereals and to sustaining biodiversity (livestock and feed sources) as measures to cope with climate uncertainties.

7. Improved livestock capacity to cope with climate change through the identification and improvement of local breeds adapted to the local feed resources and tolerant to heat or cold stress.

8. Develop knowledge, livelihood strategies and modern tools to forecast information on biophysical, economical and markets environment to agropastoral communities [16].

\section{Crops and biodiversity conservation}

By far the most significant impact of agriculture on biodiversity is the conversion of highly diverse forests and other natural habitats into much simpler pastures or agricultural systems. An ecological rule of thumb is that a $30 \%$ or greater loss of natural vegetation leads to major shifts in wild biodiversity.

Converting native forests into grasslands, and forests or grasslands into croplands, leads to the loss of most native plant species and the animals that depend on them. Populations of below-ground organisms are also affected when the main vegetation cover is radically altered. While a majority of food production comes from intensive crop and livestock systems, these account for only a quarter and perhaps as little as a sixth of the total land area that is being utilized for - and thus ecologically impacted by agriculture.

Today's crop varieties are not adapted to the conditions to which they have never before been exposed. In many areas, the coldest growing seasons of the future will be hotter than anything experienced in the past. As early as 2030 - fifty years before the situation depicted here maize production will drop by more than $25 \%$ unless we move now to help maize adapt to rising temperatures.

Food production needs to be increasing. Instead, production will stagnate or fall in absolute terms in many developing countries. On a per capita basis, food production will decrease dramatically. If we are to avoid a global food crisis on a scale never before experienced, we will need climate-ready crops in the field, no later than 2030. This is two breeding cycles away for crops such as maize and wheat. As the Declaration of the World Summit on Food Security (2009) put it:

'Any recipe for confronting the challenges of climate change must allow for mitigation options and a firm commitment to the adaptation of agriculture, including through conservation and sustainable use of genetic resources for food and agriculture.'

Crop diversity conservation and use must be recognized as an essential element of the commitments countries will make for climate change adaptation. It is a prerequisite for the success of all climate change adaptation initiatives, the 
biological foundation of food security and national economies $[17,18]$.

\section{Role of science and technology}

It is clear from the above that the drylands face a massive challenge because of climate change. What could science and technology do to improve the capacity of the dryland inhabitants to cope with it? Science and technology can certainly make a huge difference, particularly with the recent availability of new tools and technologies. The new tools, amongst other, include geographic information systems and remote sensing, simulation modeling, biotechnology and genetic engineering, advance artificial intelligence, techniques to harvest renewable energy (solar, wind, second and third generation biofuels), new energy-saving techniques to desalinize sea water and transporting it, and nanotechnology [4,19-21].

\section{Adaptation tools to confront climate change impact Application of biotechnology for dryland agriculture}

Water stress caused by drought and salinity is the most important abiotic factor limiting plant growth and crop productivity in arid lands. Therefore, enhancing osmotic stress tolerance in crops grown under such conditions could provide a solution to this problem [22]. High genetic diversity exists for the components of abiotic stress response in genetic resources collected from the dry areas. This resource has to be properly evaluated and documented for future use. In addition to field evaluation in stressed environments, where the individual stress effect cannot usually be separated from the multiplestress response, germplasm characterization in controlled conditions using morphophysiological criteria may reveal new evidence on different components of the abiotic stress response. Moreover, advances in molecular biology open new opportunities for understanding the physiological and genetic mechanisms involved in plant response to different stresses and provide tools for molecular screening and genetic engineering applications in crop improvement for increased abiotic stress tolerance. A thorough evaluation and exploration of genetic diversity existing in the crops' wild relatives, primitive forms and landrace collections may be a strategic first step in germplasm development in the extensive arid drylands.

For the structural characterization of the germplasm collection, microsatellite-based markers, also known as simple sequence repeats (SSRs), are the most promising for genome analysis in cereal crops and leguminous crops. Either genomic or expressed sequence tag (EST)derived SSRs are ideal DNA markers for population studies and genetic mapping because of their abundance, high level of polymorphism, dispersion throughout diverse genomes, ease of an assay by PCR, and ease of dissemination of the technology among laboratories
High-throughput genotyping has become an integral part of most advanced breeding programs. Single nucleotide polymorphisms (SNPs) serve as bi-allelic genetic markers and they are used because of their high occurrence in genomes. Technological improvements make the use of SNP markers attractive for high-throughput EST mapping, the integration of genetic and physical maps and use in marker-assisted breeding.

Developments in large-scale, high-throughput technologies and robotics now allow researchers to simultaneously profile vast numbers of different genes or proteins. Microarrays and functional genomics will permit researchers to screen tens of thousands of genes in multiple tissues under a myriad of experimental conditions and would therefore improve the efficiency of breeding for abiotic stress [23].

\section{Examples of biotechnology application for drylands}

The application of molecular biology and biotechnology offers great promise in overcoming crop-production constraints in drylands. For example, grasspea (Lathyrus sativus) is the most drought-tolerant legume used as feed and food in countries such as Ethiopia, Bangladesh and India. Consumption of grasspea seeds in large quantities by humans and animals can lead to lathyrism or paralysis of the legs because of the presence of a neurotoxin in the seeds. Recently, tissue culture regeneration protocols have been used to obtain plants with a low concentration of that neurotoxin through somaclonal variation. Somaclonal lines were identified that expressed consistently lower levels of the neurotoxin. These are being multiplied in Ethiopia after testing [24].

Quantitative trait loci (QTL) analysis is an important component of crop improvement strategy for dry areas. For QTL analysis, homozygous populations such as recombinant inbred lines or doubled haploid wheat and barley populations are required. Doubled haploid lines are completely homozygous and therefore provide more accurate correlation between DNA markers and agronomic traits [25]. They also allow the plant breeders or geneticists to hasten the development of pure lines from the crosses as compared to conventional pedigree or bulk methods.

Radiation-frost injury is an important abiotic constraint to lentil production in the dry areas in West Asia. If the cold tolerance of lentil could be improved, early planting could increase its yield in low-rainfall areas. Recombinant inbred lines of a lentil cross were tested in northern Syria for plant frost injury levels.

Chickpea is an important dryland crop sown in spring in WANA. Its yield and water-use efficiency can be improved by advancing its date of sowing to winter. Ascochyta blight, a fungal disease attacking chickpea, has developed into a major threat for winter-grown 
chickpea. DNA markers have been used to characterize the available pathotypes of chickpea. This allows the development of geographical distribution maps of the pathogen and the deployment of effective host-plant resistance genes. For tagging host-plant resistance genes in chickpea, sequence-tagged-microsatellite site markers have been developed. Host-plant resistance for Ascochyta blight is being mapped in several populations and genetic backgrounds [25].

A major transcription system that controls abscisic-acidindependent gene expression in response to dehydration and low temperature has been researched for improving the adaptation of crops for dry areas. The system is based on the fact that overexpression of the cDNA encoding Dehydration Responsive Element Binding in transgenic plants activates the expression of many genes and results in improved tolerance to drought, salt loading and freezing [25]. Recent progress in plant transformation protocols has made it possible to transfer genes from other species into crops to achieve agronomically desirable traits, such as drought and salt tolerance. One strategy is to genetically engineer plants to accumulate compatible osmolytes, such as amino acids, sugars or sugar alcohols, resulting in decreased osmotic potential and avoidance of water deficit. Another transgenic approach is to constitutively overexpress certain plant proteins, such as late embryogenic abundant proteins that accumulate during seed desiccation and in vegetative tissues when plants experience water deficit.

Field trials demonstrated that the barley HVA1 gene, encoding a member of the group 3 late embryogenesis abundant proteins, when transferred to Wheat cv. Hi-Line, has conferred drought tolerance in the tested transgenic wheat $[23,26]$. This could pave the way for the cultivation of wheat and barley varieties in the vast deserts on this planet.

\section{Nanotechnology applications in agriculture}

Nanotechnology can have wide applications in agriculture, opening enormous new opportunities such as the fabrication of nanosensors for protecting food from pathogens and pests, identification and control of insect pests and pathogens whose incidence and diversity is going to increase because of climate change, new tools for molecular and cell biology, including more efficient techniques for gene delivery for genetic engineering, and molecular nanomachines and devices. Nanotechnology has also been used by Norwegian scientists to stabilize sand dunes [4]. Nanotechnology is already picking up the pace in different parts of the world, including some developing countries. The use of nanotechnology in agriculture has begun, and will continue to develop with significant effects on different areas of agriculture and the food industry. This will certainly help scientists to design measures for enhancing the resilience of people to cope with the adverse effects of climate change.

\section{The way forward}

In light of what has been presented above, the way forward for enhancing the resilience of dry area inhabitants to cope with the challenges of climate change includes several essential elements. These include:

1. Better assessment of climate change scenarios by carrying out assessments at the regional, national and local levels to navigate through and across scales.

2. Rapid transition to intersectoral thinking, institution building, planning and policy making for responsible and sustainable agriculture, including aquaculture and fishery.

3. Coping with uncertainty, recognizing that there will be a shifting of the baseline as further assessment of climate change is done.

4. Essential increased investment in research and information systems.

We need to work together - communities, policy makers and scientists. Therefore, we have to forge a strong global alliance for the food security, peace and prosperity of people living in drylands under the changing climate.

\section{Conclusions}

We are passing through a time in which social, political and economic realities are changing and a growing recognition of collective responsibility, facilitated by modern information technology, is driving the struggle for change. We also know that open-market economics will bring about major changes in the agriculture of tomorrow. The time is right for us to choose the path that will safeguard our future.

Today, we have the right expertise and tools to fight desertification. We must continue to improve the awareness of the frightening consequences of its effects on people, particularly those living in poverty, to generate support from national governments to join with international teams to fight this menace. Our efforts to increase the productivity of the arid lands and the sustainability of its resources have the objective of enabling humanity to achieve a better life, and to pass on an improved legacy to the future generations.

We have most of the means for coping with the problem we face, but are distinctly short on our readiness to use them. We need new systems, new teams and new economics. Moreover, we need a new moral compass to guide us into the twenty-first century - a compass grounded in 
the principles of meeting human needs sustainably [27]. By working together, we can achieve this objective.

\author{
Abbreviations \\ CWANA: Central West Asia and North Africa; EST: expressed sequence tags; \\ ICARDA: International Centre for Agricultural Research in the Dry Areas; IPCC: \\ Intergovernmental Panel on Climate Change; $\mathrm{N}_{2} \mathrm{O}$; nitrous oxide; PCR: \\ polymerase chain reaction; QTL: quantitative trait loci; SNP: single nucleotide \\ polymorphism; SSR: simple sequence repeats; WANA: West Asia and North \\ Africa.
}

\section{Authors' contributions}

$A B$ and $M M$ participated jointly in the conception, design and acquisition of data for the paper and outlined the main sections to be discussed. MM helped to draft the manuscript and prepared it in its final form for submission, while $A B$ provided the figures. All authors read and approved the final manuscript.

\section{Competing interests}

The authors declare that they have no competing interests.

Received: 27 January 2012 Accepted: 22 March 2012 Published: 19 April 2012

\section{References}

1. Intergovernmental Panel on Climate Change (IPCC): Synthesis Report 2001. Contribution of Working Group I, II, and III to the Third Assessment Report of the Intergovernmental Panel on Climate Change Cambridge: Cambridge University Press; 2001.

2. Intergovernmental Panel on Climate Change (IPCC): Summary for Policymakers. In Climate Change 2007: impacts, adaptation and vulnerability. Contribution of Working Group II to the Fourth Assessment Report of the Intergovernmental Panel on Climate Change. Edited by: Parry ML, Canziani OF, Palutiko JP, van der Linden PJ, Hanson CE. Cambridge: Cambridge University Press; 2007:

3. Fargues P, Salinari G: Migratory flows and demographic transition. Longterm evolution and future scenarios. Tomorrow, the Mediterranean. Scenarios and projections for 2030 Paris, France: IPEMED; 2011, 69-108.

4. El-Beltagy A: Enhancing resilience in dry areas to cope with vagaries of climate change. Proceedings of the 9th International Conference on the Development of Drylands: November 7-10 2008; Alexandria, Egypt IDCC; 2008, 69-76.

5. World Fish Center: Climate Change: Research to Meet the Challenges Facing Fisheries and Aquaculture. Issues Brief 1915 World Fish Center; 2009.

6. Anderson S, Morton J: Drylands and climate change. Social dimensions of climate change workshop International Institute for Environmental Development; 2008.

7. Millennium Ecosystem Assessment: Ecosystems and human well-being: Synthesis. 2005 [www.millenniumassessment.org/documents/ document.356.aspx.pdf].

8. Campbell B, Hagmann J, Stroud A, Thomas R, Wollenberg E: Navigating amidst complexity. Guide to implementing effective research and development to improve livelihoods and the environment. 2006 [http:// www.icarda.cgiar.org/publications/navigatingamidstcomplexity.pdf].

9. World Development Report: Development and Climate Change. Overview: changing the climate for development. Washington, DC: The World Bank; 2010.

10. Clarke J, Noin D: In Population and Environment in Arid Regions. Man and Biosphere series. Volume 19. Nachville, USA: Parthenon Publishing; 1998.

11. Periera L: Irrigation demand management to cope with drought and water scarcity. In Water Science and Technology Library, Tools for Drought Mitigation in Mediterranean Regions. Volume 44. Dordrecht, Germany: Kluwer Academic Publishers; 2003:19-33.

12. El-Beltagy A: Land degradation: a global and regional problem. In Human Development and the Environment. Challenges for the United Nations in the New Millennium. Edited by: van Ginkel H, Barrett B, Court J, Velasquez J. Tokyo, New York, Paris: United Nations University Press; 2006:245-263.

13. Oweis $T$, Hachum A: Improving water productivity in the dry areas of West Asia and North Africa. In Water Productivity in Agriculture: Limits and
Opportunities for Improvement. Edited by: Kijne JW, Barker R, Molden DJ. Wallingford, UK: CABl; 2003:179-198.

14. Padgham J: Agricultural development under a changing climate: opportunities and challenges for adaptation. The World Bank 2009 [http:// www.preventionweb.net/files/11832_climatechangecombined1.pdf].

15. Rosenzweig C, Tubiello F: Adaptation and mitigation strategies in agriculture: an analysis of potential synergies. Mitigation and Adaptation Strategy for Global Climate Change 2007, 12:855-873.

16. Nefzaoui A, El-Mourid M: Coping with climate change and risk management strategies for a sustainable livestock and Rrangeland systems in the WANA region. Proceedings of the 19th International Conference on Development of Drylands: 7-10 2008; Alexandria, Egypt IDCC; 2008, 630-640.

17. McNeely J, Scherr S: Ecoagriculture; Strategies to Feed the World and Save Biodiversity Washington, D.C.: Island Press; 2003.

18. Masundire $\mathrm{H}$ : The role of biodiversity in the provision of drylands ecosystem goods and services. In Challenges for Drylands in the New Millennium: A Cross-cutting Approach for Assessment. Edited by: Adeel Z, Clancy D, Dubreuil A. Tokyo, New York, Paris: United Nations University International Network on Water; 2003:55-68, [Unu Desertification Series No. 6].

19. El-Beltagy A: Reversing desertification: The potential for research. Proceedings of the 6th International Conference on the Development of Drylands. Cairo, Egypt - Keynote 1999.

20. Tsunekawa A: New challenges for science and technology in dryland development - bridging dryland science and on-the ground practice. Proceedings of the 9th International conference on Development of Drylands. Alexandria, Egypt IDCC; 2008, 99-103.

21. Mendelsohn R: Climate Change. Measuring climate change impacts with cross sectional analysis 2007, 81(Special)::118.

22. Madkour M: Biotechnology and its application in agriculture and food production: the Egyptian experience. Biotechnology and sustainable development: Voices from the South and North Wallingford, UK: CABI publishing; 2003, 55-66.

23. Madkour M: Harnessing new science to meet the challenges of drought. In Changing lives, BioVision, Alexandria 2006. Edited by: Serageldin I, Masood E. Alexandria, Egypt: Bibliotheca Alexandrina; 2007:299-310.

24. Abd-El-Moneim A, van Dorrestein B, Baum M: Improving the nutritional quality and yield potential of grasspea (Lathyrus sativus L). Food Nutrition Bull 2000, 21:493-496.

25. Baum M, Grando S, Backes G: QTLs for agronomic traits in the Mediterranean environment identified in recombinant inbred lines of cross "Arta" × H. spontaneum. Theor Appl Genet 2003, 107(7):1215-1225.

26. Bahieldin A, Mahfouz H, Eissa H, Saleh O, Ramadan A, Ahmed I, Dyer W, ElItriby H, Madkour M: Field evaluation of transgenic wheat plants stably expressing HVA1 gene for drought tolerance. Physiol Plant 2005, 123:421-427.

27. Fyfe W: Toward ecoresponsibility: the need for new education, new technologies, new teams and new economics. In Managing for healthy ecosystems. Edited by: Lasley WL, Rapport DJ, Damania AB, Rolston DE, Nielsen NO, Qualset CO. Boca Raton, USA: CRC Press; 2002:21-25.

doi:10.1186/2048-7010-1-3

Cite this article as: El-Beltagy and Madkour: Impact of climate change on arid lands agriculture. Agriculture \& Food Security 2012 1:3.

\section{Submit your next manuscript to BioMed Central and take full advantage of:}

- Convenient online submission

- Thorough peer review

- No space constraints or color figure charges

- Immediate publication on acceptance

- Inclusion in PubMed, CAS, Scopus and Google Scholar

- Research which is freely available for redistribution 